\title{
Travel behaviour after the pandemic: the case of Bulgaria
}

\section{Maya Ivanova*}

1. Associate Professor, Varna University of Management, 13A Oborishte Str., 9000 Varna, Bulgaria, tel: +35952300680, e-mail: maya.ivanova@vumk.eu

2. CEO, Zangador Ltd., 9010 Varna, Bulgaria

ORCID: 0000-0002-9270-7892

Ivan Krasimirov Ivanov

BA (Hons) International Hospitality Management graduate, Varna University of Management, 13A Oborishte Str., 9000 Varna, Bulgaria; email: ivan.krasimirov.ivanov96@gmail.com

\section{Stanislav Ivanov}

Professor, Varna University of Management, 13A Oborishte Str., 9000 Varna, Bulgaria, tel: +35952 300 680, e-mail: stanislav.ivanov@vumk.eu. Personal website:

http://www.stanislavivanov.com

ORCID: 0000-0002-6851-5823

\section{*Corresponding author}

\begin{abstract}
The paper analyses the travel intentions of tourists in the post-pandemic world. The sample includes 974 respondents from Bulgaria. The findings show that most of the respondents are ready to travel within two months after travel is allowed in the country. For their first trip, respondents will travel in the country, by their car and with their family. Hygiene, disinfection and reliable health system in a destination will be the leading factors in travellers' decisions, according to the findings. Women and older respondents have higher health and safety preferences than do men and younger respondents.
\end{abstract}

Keywords: COVID-19; travel behaviour; travel motivations; post-viral tourism; Bulgaria

Citation: Ivanova, M., Ivanov, I. K., \& Ivanov, S. (2020). Travel behaviour after the pandemic: the case of Bulgaria. Anatolia (in press). doi: https://doi.org/10.1080/13032917.2020.1818267 


\section{Introduction}

At the beginning of 2020, the world evidenced an unprecedented situation caused by the COVID-19 pandemic. Although there were other similar epidemics such as Ebola, SARS, MERS in the previous decades (Gössling, Scott, \& Hall, 2020), the world had not faced any other disaster with such a massive and deleterious effect on the economy and society (Naumov, Varadzhakova \& Naydenov, 2020). While all sectors of the economy suffered a great deal from the lockdown, quarantine, and border closures (Goodell, 2020), tourism and hospitality industries appeared as the biggest (and most immediate) losers of the crisis (Gössling, Scott, \& Hall, 2020). The closed borders prevented scheduled flights and the quarantine measures imposed by the governments limited the opportunities to travel to a great extent (Nicola et al., 2020).

Moreover, many tourism businesses went into default or registered huge losses, because of limited travel consumption (Wen, Kozak, Yang, \& Liu, 2020). As the growth of infections started to slow down, governments commenced strategies to resume travel and restore economic growth (Fakhruddin, Blanchard \& Ragupathy, 2020; Collins, 2020). Preparation for the restart requires a considerable transformation within the tourism sector, including a significant amount of reorganisation and the integration of new protocols and standards (Lew, Cheer, Haywood, Brouder, \& Salazar, 2020). Meanwhile, consumers also changed because of the pandemic, namely their perceptions, preferences and attitudes to travel (Peters, Peters, \& Peters, 2020). Therefore, companies' business strategies following the pandemic inevitably should consider the changes in tourists' behaviour and demand (Brouder, 2020).

Tourism demand has traditionally reacted to disasters through severe declines and changes (Page, Song, \& Wu, 2011). The tourism industry has long been recognised as vulnerable to disastrous events, implying risk for personal safety, security or health (Cró \& Martins, 2017; Estevão \& Costa, 2020). Hence, the process of recovery after any disaster or force majeure situation requires research on the shifting consumers' attitudes and perceptions, to understand the changes in the characteristics of the demand.

Soon after the COVID-19 outbreak, numerous publications explored this novel phenomenon and its impact on the lives of citizens and specifically on the travel and tourism industry (Brouder et 
al., 2020). The majority of studies focus on the current effects and the negative consequences over diverse economic sectors (Goodell, 2020; Nicola et al., 2020), including tourism. The studies examine deeply the supply-side perspective, estimating the damage caused, forecasting the consequent changes and remodelling of the tourist offers (Gössling, Scott, \& Hall, 2020). However, the demand side studies remain quite scarce (Zencker \& Kock, 2020), probably because of the uncertainty in the economic aspect and the persisting risk of infection. Yet, a few papers investigated the emerging signs of consumers' recovery and a readiness to renew their travel.

Being the first to announce a lockdown and the first to open, China pioneers the strategies to revive its tourism industry (Wen, Kozak, Yang, \& Liu, 2020). The Chinese tourists are expected to travel mostly domestically due to the limitted international flights. Understandably, tourists feel safer when travelling shorter distances from home (Enger et al., 2020). Self-guided and selfdriven trips will dominate over the group and organised tour packages (Enger et al., 2020), which is a significant change for the Chinese tourists, who are known to prefer guided group tours and special care during their trips (Wen et al., 2020). In a similar vein, the British are eager to book a trip once travel is broadly permitted (Collins, 2020), but because of international restriction, they probably will stay on the isles, thus enhancing domestic tourism in the UK. However, their absence in other countries (Spain, France, Portugal) should have a negative impact on tourism in those destinations (Collins, 2020), due to the change in tourism flows.

A recent study by the US Travel Association and MMGY Travel Intelligence on the travel intentions of US citizens identifies the readiness of Americans (57\%) to go on a domestic trip (MMGY Travel Intelligence, 2020a). Driving, even for longer distances, is a preferred transport for one-third of the respondents, and the younger travellers are most likely to initiate a trip in the forthcoming months (MMGY Travel Intelligence, 2020a). Elliott (2020) reports almost the same implications about the US travel demand. The most common motives for travel among Americans are business meetings, road trips, and luxury getaways. Also, some special types of trips will gain popularity in the post-pandemic period, like camping, couch surfing, recreational vehicles and any other safe summer vacation ideas (Elliott, 2020). De Vos (2020) also forecasts 
an increased interest in activities such as walking and cycling as a means to overcome the negative physical and psychological health effects of the forced social distancing.

Sanitary precautions and health care have risen their importance as factors linked with travel demand. It is interesting to note, however, that the stated intentions of Middle Eastern consumers to travel depend more on the sense of safety and governmental policy, rather than on the availability of a vaccine for the COVID-19 (Choufany, 2020). The most recently published studies of the post-pandemic travel behaviour in Greece (Kourgiantakis, Apostolakis, \& Dimou, 2020) and Indonesia (Wachyuni, \& Kusumaningrum, 2020) show that the pandemic seems to generate concern and uncertainty on multiple aspects of consumers' everyday life (Kourgiantakis et al., 2020), but still people have a positive attitude towards travelling and do not reveal any excessive anxiety (Wachyuni, \& Kusumaningrum, 2020). Despite the geographical and cultural distances, customer surveys resemble the Chinese model of demand trends (Enger et al., 2020). Industry players might consider those emerging trends, to modify their product according to the early demand preferences and capture the first opportunities for restoring the business.

In the context of the above discussion, this article adopts a demand-side perspective and focuses on the willingness to travel and preferences of Bulgarian consumers. By examining the travel intentions, the study facilitates the tourism businesses in elaborating or adapting their offers to meet the changing demand. Moreover, the results provide insights about the pace of the recovery of the tourism demand in the country.

\section{Methodology}

Data were collected from 07 April to 07 May 2020. The researchers developed an online questionnaire, based in Qualtrics XM, and the link to it was distributed through social media. The questionnaire included several blocks of questions. The first block captured the demographic characteristics of the respondents - age, gender, monthly household income, education, marital status and previous travel experience (number of trips in the last 12 months). The second block of questions asked about the intentions to travel, the planned frequency of travel as well as the first intended destination to visit. Important aspects of post-pandemic travel behaviour such as travel motivation, preferred transport, and accompanying persons formed the third block. The 
tourists' perceptions of the new hygiene and physical distancing protocols are explored in the next two blocks of questions. The final sample included 974 respondents. The skewness and kurtosis values were all were within $[-2 ;+2]$ range and most values were within the range [-1; $+1]$. Therefore, considering the large sample size (over 500 respondents), the empirical distribution of responses was considered as being close to normal (Kim, 2013) which allowed the use of parametric tests for data analysis. The data was processed and analysed through SPSS 24.0 using descriptive statistics, cross-tabulations, t-tests, ANOVA, and multinomial regression analysis.

\section{Results}

Females are a strong majority of respondents ( $80.1 \%$ from the total sample), whereas the age groups are almost evenly represented (25.7\% of respondents were within the 18-30 age group, $26.4 \%-31-40,28.1 \%-41-50,14.9 \%-51-60$, and $4.9 \%$ were over 60 years old). The majority of respondents have college or university degrees $(79.6 \%)$, but these are also the people who travel the most. The previous travel experience (number of trips in the last 12 months) is useful to illustrate if the COVID-19 pandemics has influenced the regular travel style of the respondents. The intense travel experience of 50.6\% (more than 4 trips per last 12 months) shows that respondents were active travellers.

Regarding the most significant question for the tourism industry (when will tourists renew their trips), the results show that 33.1 percent of respondents indicate that they are going to travel within less than a month after travel is allowed, and a further 30.2 percent will travel within 1-2 months after travel is allowed. The fact that Bulgaria was not so severely affected by the pandemics (160 casualties as of $8^{\text {th }}$ June 2020 , but less than 90 by the end of the data collection according to Worldometers, 2020) made the respondents quite optimistic and eager to renew their travel habits. It is additionally supported by the fact that 65.2 percent of respondents intend to travel as frequently as in the period before the pandemic. This is a really good sign for the rapid recovery of the tourism industry, enhanced even further by the fact that 10.4 percent of the respondents claim that they are going to travel more than in the period before the pandemics. 
However, 53.9 percent of respondents indicate Bulgaria is their first-choice destination for travel following the lifting of travel restrictions, rather than any destination abroad. At the time of data collection, most of the borders were still closed without any forecasts to open soon. Moreover, the results may reflect people's reluctance to travel because of the risk of infection, or probably due to the limited available funds after the period of quarantine. The findings are in line with the results of similar studies in China, Europe, Middle East and USA (Choufaney, 2020; Collins, 2020; Elliott, 2020; Enger et al., 2020; Glusac, 2020; Kourgiantakis et al., 2020) where respondents' behaviour follows the same model - domestic or short-distance trips. Kourgiantakis et al. (2020) consider that the preference for domestic trips is a shift towards localism in tourism consumption as a result of the pandemic.

Tables 1 and 2 show the distribution of respondents' answers regarding travel intentions, frequency of travel, and first destination to visit, according to the monthly household income, previous travel experience, age, and gender. The most eager to travel within less than a month after the travel is allowed are those, who used to have 6 or more trips for the last 12 months (154 out of 271 , i.e. $56.8 \%$, Table 1). It is interesting to note that the next most active group of travellers are those, who travelled 1-3 times for the last year - 52.4 percent (218 out of 416) from them intend to travel again within 2 months after travel is allowed.

Expectedly, the higher the monthly income, the more respondents are willing to travel $(\chi 2=261.395, \mathrm{p}=0.000)$. Regarding the age distribution, the respondents who will first restart their trips are between 31-40 and 41-50 years old, i.e. the most active part of the working adult population (see Table 2). A very interesting paradox is found for the response of the first destination choice - younger people (less than 50 years old) choose Bulgaria or domestic travel as their first post-pandemic destination, whereas people from the age groups over 51 years of age are almost evenly distributed in their destination choice - within the country or abroad. Considering the latter are among the riskiest groups who should avoid trips, it is quite noteworthy that they do not express more concerns regarding their travel, whether domestic or abroad. 
Looking at the frequency of travel after the pandemic, we see that income and gender do not influence the distribution of respondents' answers ( $>>0.05)$. Frequency of travel is shaping respondents' answers $(\chi 2=13.569, \mathrm{p}=0.035)$. For example, $21.54 \%$ of people who had not travelled during the last 12 months are expecting to travel more after the pandemic, while around $10 \%$ of other respondents are planning to do so. These non-travellers might have been persuaded by the eliminated travel opportunities due to the closed borders and the lockdown. They might prefer to undertake a trip while they still have an opportunity to do so. Additionally, the findings show that $83.60 \%$ of the youngest respondents (18-30) will stay the same or increase their travel frequency while between $70-75 \%$ of the other age groups would do so $(\chi 2=18.101$, $\mathrm{p}=0.020$ ). Hence, young adults have a stronger desire to travel than other generations. However, the multinomial regression analysis (Table 3 ) shows that when considered simultaneously none of the four grouping variables (monthly household income, number of trips in the last 12 months, age, or gender) has any influence on the frequency to travel after the pandemic.

\section{[Insert Table 1, Table 2 and Table 3 about here]}

In terms of the main motivation for travel, we observe a very high share of respondents wish to travel for relaxation $(46.1 \%)$, compared to any other traditional travel motivation - e.g. business (only $7.0 \%$ ). It seems that the forced stay at home due to the government's restrictions gives citizens the urge to leave the home to relax. The popular home office and online meetings during the pandemics proved that business may run from home, and as a result, most of the business arrangements went online, without the need to travel. This result contrasts the findings from the Middle East and American markets, where the top motive for travel is business (Choufaney, 2020; MMGY Travel Intelligence, 2020a), but goes in line with the preferences of Indonesians, who search for more nature-based holidays (Wachyuni, \& Kusumaningrum, 2020).

Respondents choose the car as the preferred transport for their next trip (55.5\%). Still, air transport keeps its position with $29.1 \%$, despite the severe decline of flights and cancellations caused by the lockdown measures. Bulgarian tourists seem quite optimistic in their expectations to continue travelling by air, similar to Americans (Elliott, 2020). As per the accompanying 
person, respondents indicate that their companions will be family $(51.1 \%)$, friends $(23.2 \%)$ and spouse (15.0\%), in line with the findings of studies of Chinese tourists (Enger et al., 2020).

A closer look at the distribution of responses (Table 4) reveals that respondents with lower income have stronger preferences to air transport and tourist buses, which are used by tour operators for package trips, and the differences with the other income groups are statistically significant $(\chi 2=79.089 \mathrm{p}=0.000)$. Hence, people with lower income will probably continue to rely on organised package trips or low-cost airlines. This finding contrasts the Greek travel requirements since the latter reject the traditional organised tours (Kourgiantakis et al., 2020). Despite the geographical and cultural proximity many Bulgarians still prefer to assign the trip organisation to somebody else, rather than do it by themselves. A similar statistically significant difference $(\chi 2=31.921, \mathrm{p}=0.000)$ is evident for the respondents with less than $1000 \mathrm{BGN}$ monthly income (around 510 euros) when they choose a companion - their first choice is friends $(31.3 \%)$.

\section{[Insert Table 4 about here]}

Visiting friends and relatives has the largest share (32.0\%) as a motive for travelling among the youngest respondents (Table 5). The other age groups prefer either relaxation or sightseeing. Regarding preferred transport, we observe a decreasing trend in choosing air transport with the increase in age $\left(\chi^{2}=72.483, \mathrm{p}=0.000\right)$. Thus, older respondents tend to prefer tourist bus, i.e. organised trips. Another statistically significant difference $(\chi 2=91.311, p=0.000)$ is found for the preferred companion among youngsters (18-30 years old) who choose to travel alone or have a friend to share the trip.

\section{[Insert Table 5 about here]}

The pandemic will undeniably have an impact on travel behaviour and the choice of a destination or an accommodation establishment. Findings from Table 6 indicate that respondents will take extra hygiene precautions in their future trips $(\mathrm{m}=4.07)$, will avoid crowds whenever possible $(\mathrm{m}=3.92)$, and will consider the health/safety of the destination when choosing a trip $(\mathrm{m}=3.89)$. 
Safety and cleanliness seem to be the most significant "new" characteristics of the travel behaviour since they are underlined in all other studies as well (Wachyuni, \& Kusumaningrum, 2020; Kourgiantakis et al., 2020). Bulgarians' perceptions about the level of importance of the different factors that would influence their travel decision are presented in Table 7.

While a remote/isolated destination $(\mathrm{m}=2.67)$ or hotel $(2.60)$ do not matter a lot, respondents are more concerned about the quality of the disinfection control of rooms and facilities $(\mathrm{m}=3.87)$, a reliable health system in the destination $(\mathrm{m}=3.56)$, and the availability of masks and sanitizers $(m=3.32)$. Bulgarians seem to appreciate the reliable health system of a destination, rather than its location or popularity, and hygiene precautions in the hotels, rather than its size or location. The t-test reveals that women have much higher safety preferences than men (all $t$-values in Table 6 and most of the t-values in Table 7 are significant at $p<0.001$ ), while the ANOVA shows that youngest respondents (18-30 years old) have lower safety preferences than older respondents. Obviously, the stigma of risk of infection has fastened its roots in people's minds and will further determine its importance as the new driver of tourist demand (MMGY Travel Intelligence, 2020b).

[Insert Table 6 and Table 7 about here]

\section{Conclusion and implications}

The tourism industry is yet to recover from the pandemic. For the business, it is crucial to hear the voices of customers and consider changes in travel demand. This study explored Bulgarians' readiness and willingness to restart their travel after the lockdown. The main insights have many common conclusions with similar studies in the USA, China and other countries. Still, Bulgarians seem optimistic and eager to return to their regular travelling habits, but they have also adopted the "new" protocol as an additional standard in the tourism industry. The main characteristics of post-pandemic travel behaviour of Bulgarians stemming from the research are:

$\checkmark$ The majority of the respondents are ready to restart travelling within 2 months after travel is allowed;

$\checkmark$ For their first trip, respondents will travel in the country, by car and with their family; 
$\checkmark$ People with lower income will rely mainly on trips by bus or air organised by tour operators when such trips are allowed and available;

$\checkmark$ Bulgarians will select destinations according to hygiene and safety;

$\checkmark$ Respondents appreciate more the destinations with the most reliable health system and the reliable disinfection systems in the destination's accommodation establishments. The findings reveal the changes in the travel behaviour of Bulgarians and point out the importance of hygiene, disinfection, reliable health system and overall perception of personal safety and security (Çelik \& Dedeoğlu, 2019; Wijaya et al., 2018; Kourgiantakis et al., 2020; AlSaad, Ababnehand, \& Alazaizeh, 2019). In that way, the results could help Bulgarian and foreign tourism suppliers in developing proper marketing strategies to attract Bulgarian tourists, following the pandemic. Emphasis on tranquillity and relaxation would be beneficial for the destinations' promotion, whereas tour operators should consider the limited available financial resources of the potential tourists, and to adapt their offers accordingly, preferably for domestic travel. Additionally, the outlined preferences would further require accommodation establishments and other companies to introduce new health and safety protocols to address travellers' preferences and legal requirements. Finally, the findings show that the travel behaviour of Bulgarians in the post-pandemic period might follow similar patterns as the travel behaviour of the residents of other countries (Choufany, 2020; MMGY Travel Intelligence, 2020a; Kourgiantakis et al., 2020), which will further facilitate travel suppliers to elaborate their products according to the "new" travel behaviour. The main limitation of the research is that focuses on consumers in one country only. Future research should focus on the actual travel behaviour of people after the pandemic to find whether the forecasted travel demand trends have materialised.

\section{References}

Al-Saad, S., Ababnehand, A., \& Alazaizeh, M. (2019). The influence of airport security procedures on the intention to re-travel. European Journal of Tourism Research, 23, 127141.

Brouder, P., Teoh, S., Salazar, N.B., Mostafanezhad, M., Pung, J.M., Lapointe, D., Higgins Desbiolles, F., Haywood, M., Hall, C.M., \& Clausen, H.B. (2020). Reflections and 
discussions: tourism matters in the new normal post COVID-19. Tourism Geographies, 22(3), 735-746. https://doi.org/10.1080/14616688.2020.1770325

Brouder, P. (2020). Reset Redux: Possible evolutionary pathways towards the transformation of tourism in a COVID-19 world. Tourism Geographies, 22(3), 484-490. https://doi.org/10.1080/14616688.2020.1760928

Çelik, S., \& Dedeoğlu, B.B. (2019). Psychological factors affecting the behavioral intention of the tourist visiting Southeastern Anatolia. Journal of Hospitality and Tourism Insights, 2(4), 425-450. doi: https://doi.org/10.1108/JHTI-01-2019-0005

Choufany, H.M. (2020). HVS COVID-19: Travelled and hotel guest sentiment findings Middle East. HVS. https://www.hvs.com/article/8766-hvs-covid-19-traveller-and-hotel-guestsentiment-findings-middle-east

Collins, S. (2020). COVID-19 recovery in the UK-the importance of domestic demand. HVS. https://www.hvs.com/article/8787-covid-19-recovery-in-the-uk-the-importance-ofdomestic-demand

Cró, S., \& Martins, A. M. (2017). Structural breaks in international tourism demand: Are they caused by crises or disasters? Tourism Management, 63, 3-9. https://doi.org/10.1016/j.tourman.2017.05.009

De Vos, J. (2020). The effect of COVID-19 and subsequent social distancing on travel behavior. Transportation Research Interdisciplinary Perspectives, 5, 100121. https://doi.org/10.1016/j.trip.2020.100121

Elliott, C. (May 13, 2020). Life after coronavirus: Ready to travel as soon as it's safe? So is everyone else. USA Today. https://eu.usatoday.com/story/travel/advice/2020/05/01/coronavirus-why-everyone-wanttravel-soon/3058753001/

Enger, W., Saxon, S., Suo, P., \& Yu, J. (2020). The way back: What the world can learn from China's travel restart after COVID-19. McKinsey \& Company. https://www.mckinsey.com/industries/travel-transport-and-logistics/our-insights/the-wayback-what-the-world-can-learn-from-chinas-travel-restart-after-covid-19

Estevão, C., \& Costa, C. (2020). Natural disaster management in tourist destinations: a systematic literature review. European Journal of Tourism Research 25, 2502. 
Fakhruddin, B., Blanchard, K., \& Ragupathy, D. (2020). Are we there yet? The transition from response to recovery for the COVID-19 pandemic. Progress in Disaster Science, 7, 100102. Doi: https://doi.org/10.1016/j.pdisas.2020.100102

Glusac, E. (April 15, 2020). How will COVID-19 affect future travel behavior? A travel crisis expert explains. The New York Times. https://www.nytimes.com/2020/04/15/travel/q-anda-coronavirus-travel.html

Goodell, J. W. (2020). COVID-19 and finance: Agendas for future research. Finance Research Letters, 35, 101512. https://doi.org/10.1016/j.frl.2020.101512

Gössling, S., Scott, D., \& Hall, C. M. (2020). Pandemics, tourism and global change: a rapid assessment of COVID-19. Journal of Sustainable Tourism. Advance online publication. https://doi.org/10.1080/09669582.2020.1758708

Kim, H. Y. (2013). Statistical notes for clinical researchers: assessing normal distribution using skewness and kurtosis. Restorative Dentistry \& Endodontics, 38(1), 52-54. https://doi.org/10.5395/rde.2013.38.1.52

Kourgiantakis, M., Apostolakis, A., \& Dimou, I. (2020). COVID-19 and holiday intentions: the case of Crete, Greece. Anatolia. Advance online publication. https://doi.org/10.1080/13032917.2020.1781221

Lew, A., Cheer, J.M., Haywood, M., Brouder, P., \& Salazar, N.B. (2020). Visions of travel and tourism after the global COVID-19 transformation of 2020. Tourism Geographies, 22(3), 455-466. https://doi.org/10.1080/14616688.2020.1770326

MMGY Travel Intelligence (2020a). Travel intentions pulse survey (TIPS): Impact of COVID19. U.S. Travel Association. https://www.mmgyintel.com/travel-intentions-pulse-surveytips-impact-covid-19

MMGY Travel Intelligence (2020b). Travel Safety Barometer. https://www.mmgyintel.com/travel-safety-barometer-0

Naumov, N., Varadzhakova, D., \& Naydenov, A. (2020). Sanitation and hygiene as factors for choosing a place to stay: perceptions of the Bulgarian tourists. Anatolia. Advance online publication. https://doi.org/10.1080/13032917.2020.1771742

Nicola, M., Alsafi, Z., Sohrabi, C., Kerwan, A., Al-Jabir, A., Iosifidis, C., Agha, M., \& Aghaf, R. (2020). The socio-economic implications of the coronavirus and COVID-19 pandemic: a 
review. International Journal of Surgery, 78, 185-193.

https://doi.org/10.1016/j.jisu.2020.04.018

Page, S., Song, H., \& Wu, D.C. (2011). Assessing the impacts of the global economic crisis and swine flu on inbound tourism demand in the United Kingdom. Journal of Travel Research, 51(2), 142-153. https://doi.org/10.1177/0047287511400754

Peters, K., Peters, J., \& Peters, N. (2020). Visit people Tourism Recovery. KPPM Strategy. Retrieved from: http://kppm.com.au/wp-content/uploads/2020/04/KPPM-TourismRecovery-Lit-Review-4-4-20.pdf

Wachyuni, S. S., \& Kusumaningrum, D. A. (2020). The Effect of COVID-19 Pandemic: How are the Future Tourist Behavior? Journal of Education, Society and Behavioural Science, 33(4), 67-76. https://doi.org/10.9734/jesbs/2020/v33i430219

Wen, J., Kozak, M., Yang, S., \& Liu, F. (2020). COVID-19: potential effects on Chinese citizens' lifestyle and travel. Tourism Review. Advance online publication. https://doi.org/10.1108/TR-03-2020-0110

Wijaya, S., Wahyudi, W., Kusuma, C.B., \& Sugianto, E. (2018). Travel motivation of Indonesian seniors in choosing destination overseas. International Journal of Culture, Tourism and Hospitality Research, 12(2), 185-197. https://doi.org/10.1108/IJCTHR-09-2017-0095

Worldometers (2020). Coronavirus. Bulgaria. https://www.worldometers.info/coronavirus/country/bulgaria/

Zenker, S., \& Kock, F. (2020). The coronavirus pandemic - A critical discussion of a tourism research agenda. Tourism Management, 81, 104164. https://doi.org/10.1016/j.tourman.2020.104164 


\section{Note on contributors:}

\section{Maya Ivanova}

Dr. Maya Ivanova is an Associate Professor and Head of the Department of Tourism at Varna University of Management, Bulgaria (http://www.vum.bg), and CEO of the consulting company Zangador Ltd. (http://www.zangador.eu). Her research interests include tourism and hospitality management, air transport, tourism intermediaries, platform economy. She has published in journals such as Annals of Tourism Research, Tourism Management Perspectives, International Journal of Hospitality and Tourism Administration, Tourism, and Anatolia.

\section{Ivan Krasimirov Ivanov}

Ivan Ivanov is a Bachelor student in International Hospitality Management at Varna University of Management, Bulgaria.

\section{Stanislav Ivanov}

Dr. Stanislav Ivanov is Professor and Vice Rector (Research) at Varna University of Management, Bulgaria. Prof. Ivanov is the Founder and Editor-in-chief of two academic journals: European Journal of Tourism Research (http://ejtr.vumk.eu) and ROBONOMICS: The Journal of the Automated Economy (https://journal.robonomics.science). His research interests include robonomics, robots in tourism/hospitality, the economics of technology, revenue management, etc. For more information about Prof. Ivanov visit his personal website: http://www.stanislavivanov.com 
Table 1. Intentions to travel and first destination to visit according to respondents' monthly household income and travel experience

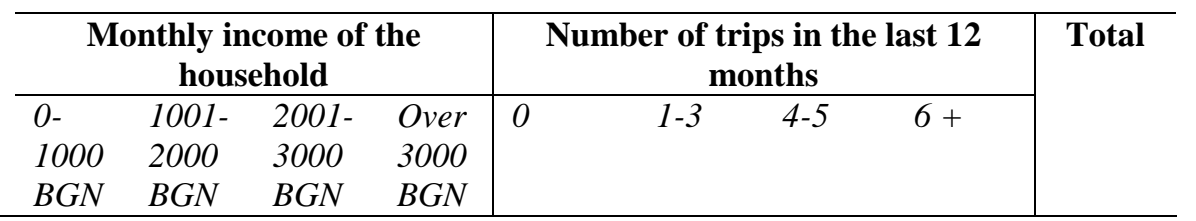

I do not intend to travel

Intentions to travel after the pandemics

Less than a month after travel is

allowed

1 - 2 months after travel is allowed

3 - 4 months after travel is allowed

5 - 6 months after travel is allowed

7 - 12 months after travel is allowed

More than 12 months after travel is

allowed

\begin{tabular}{|c|c|c|c|c|c|c|c|c|}
\hline 12 & 22 & 7 & 2 & 20 & 19 & 3 & 1 & 43 \\
\hline 53 & 112 & 69 & 88 & 9 & 89 & 70 & 154 & 322 \\
\hline 34 & 114 & 67 & 79 & 9 & 129 & 87 & 69 & 294 \\
\hline 18 & 64 & 32 & 28 & 5 & 77 & 33 & 27 & 142 \\
\hline 9 & 27 & 23 & 13 & 6 & 46 & 11 & 9 & 72 \\
\hline 15 & 20 & 14 & 13 & 7 & 35 & 12 & 8 & 62 \\
\hline 9 & 20 & 9 & 1 & 9 & 21 & 6 & 3 & 43 \\
\hline $2=43$ & $1(\mathrm{df}=$ & $=0$. & & $\chi^{2}=2$ & 95 & $p=$ & & \\
\hline
\end{tabular}

I will travel less compared to the period before the pandemic

I will travel as frequently as in the

period before the pandemic

I will travel more than in the period

42

90

$51 \quad 55$

I will travel more than
before the pandemic

$96 \quad 241 \quad 146 \quad 152$

$\begin{array}{llll}12 & 48 & 24 & 17\end{array}$

$\chi 2=5.933(\mathrm{df}=6, \mathrm{p}=0.431)$

\begin{tabular}{|lllll|l}
10 & 108 & 60 & 60 & 238
\end{tabular}

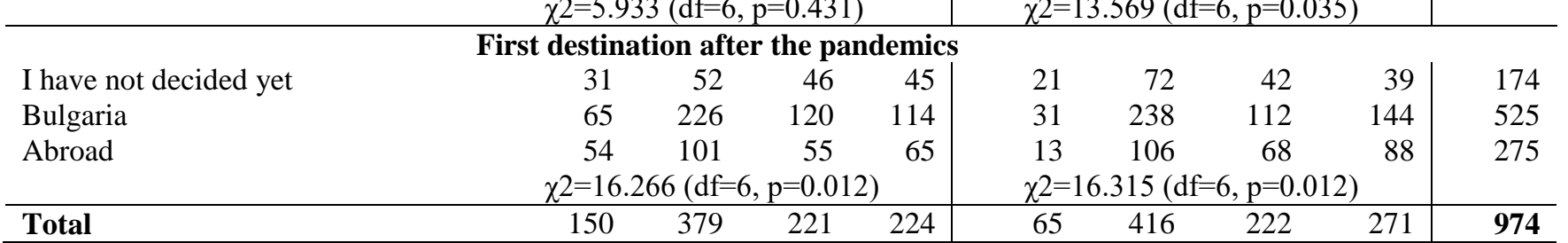


Table 2. Intentions to travel and first destination to visit according to age and gender of the respondents

\begin{tabular}{|c|c|c|c|c|c|c|c|c|}
\hline & \multicolumn{5}{|c|}{ Age (years old) } & \multicolumn{2}{|l|}{ Gender } & \multirow[t]{2}{*}{ Total } \\
\hline & $18-30$ & $31-40$ & $41-50$ & $51-60$ & $61+$ & Female & Male & \\
\hline \multicolumn{9}{|c|}{ Intentions to travel after the pandemics } \\
\hline I do not intend to travel & 18 & 14 & 4 & 4 & 3 & 29 & 14 & 43 \\
\hline Less than a month after travel is allowed & 78 & 90 & 106 & 39 & 9 & 250 & 72 & 322 \\
\hline $1-2$ months after travel is allowed & 66 & 86 & 84 & 45 & 13 & 241 & 53 & 294 \\
\hline 3 - 4 months after travel is allowed & 43 & 24 & 39 & 29 & 7 & 113 & 29 & 142 \\
\hline 5 - 6 months after travel is allowed & 23 & 15 & 19 & 9 & 6 & 59 & 13 & 72 \\
\hline $7-12$ months after travel is allowed & 15 & 17 & 12 & 9 & 9 & 52 & 10 & 62 \\
\hline More than 12 months after travel is & 7 & 11 & 10 & 10 & 1 & 36 & 3 & 39 \\
\hline & \multicolumn{5}{|c|}{$\chi^{2}=52.649(\mathrm{df}=24, \mathrm{p}=0.001)$} & \multicolumn{2}{|c|}{$\begin{array}{c}\chi^{2}=10.562 \\
(\mathrm{df}=6, \mathrm{p}=0.103)\end{array}$} & \\
\hline \multicolumn{9}{|c|}{ Frequency of travel after the pandemics } \\
\hline $\begin{array}{l}\text { I will travel less compared to the period } \\
\text { before the pandemic }\end{array}$ & 41 & 67 & 82 & 35 & 13 & 203 & 35 & 238 \\
\hline $\begin{array}{l}\text { I will travel as frequently as in the period } \\
\text { before the pandemic }\end{array}$ & 174 & 164 & 173 & 95 & 29 & 496 & 139 & 635 \\
\hline I will travel more than in the period before & 35 & 26 & 19 & 15 & 6 & 81 & 20 & 101 \\
\hline & \multicolumn{5}{|c|}{$\chi 2=18.101(\mathrm{df}=8, \mathrm{p}=0.020)$} & \multicolumn{2}{|c|}{$\begin{array}{c}\chi 2=5.602(\mathrm{df}=2 \\
\mathrm{p}=0.061)\end{array}$} & \\
\hline \multicolumn{9}{|c|}{ First destination after the pandemics } \\
\hline I have not decided yet & 58 & 37 & 50 & 24 & 5 & 133 & 41 & 174 \\
\hline Bulgaria & 146 & 156 & 142 & 59 & 22 & 429 & 96 & 525 \\
\hline Abroad & 46 & 64 & 82 & 62 & 21 & 218 & 57 & 275 \\
\hline & \multicolumn{5}{|c|}{$\chi 2=40.782(\mathrm{df}=8, \mathrm{p}=0.000)$} & \multicolumn{2}{|c|}{$\begin{array}{c}\chi 2=2.439(\mathrm{df}=2 \\
\mathrm{p}=0.295)\end{array}$} & \\
\hline Total & 250 & 257 & 274 & 145 & 48 & 780 & 194 & 974 \\
\hline
\end{tabular}


Table 3. Multinomial regression analysis

\begin{tabular}{|c|c|c|c|c|c|c|c|c|c|c|c|c|c|c|c|c|}
\hline \multirow{2}{*}{$\begin{array}{l}\text { Frequency of travel after the } \\
\text { pandemics }\end{array}$} & \multicolumn{8}{|c|}{ Same frequency vs Lower frequency } & \multicolumn{8}{|c|}{ Same frequency vs Higher frequency } \\
\hline & \multicolumn{2}{|c|}{$\begin{array}{ll}\text { B } & \text { Std. } \\
& \text { Error }\end{array}$} & Wald & df & $\operatorname{Exp}(B)$ & \multicolumn{2}{|c|}{$\begin{array}{l}95 \% \text { Confidence } \\
\text { Interval for } \operatorname{Exp}(B)\end{array}$} & Sig. & B & $\begin{array}{l}\text { Std. } \\
\text { Error }\end{array}$ & Wald & & $\operatorname{Exp}(B)$ & $\begin{array}{l}95 \% \mathrm{C} \\
\text { Interva } \\
\text { Lower } \\
\text { Bound }\end{array}$ & $\begin{array}{l}95 \% \text { Confidence } \\
\text { Interval for } \operatorname{Exp}(B)\end{array}$ & Sig. \\
\hline Intercept & -1.424 & 0.430 & 10.975 & 1 & & & & 0.001 & -1.846 & 0.589 & 9.828 & 1 & & & & 0.002 \\
\hline $\begin{array}{l}\text { Monthly household income } \\
\text { 0-1000 BGN } \\
\text { 1001-2000 BGN } \\
\text { 2001-3000 BGN } \\
\text { Over 3000 BGN (ref) }\end{array}$ & \begin{tabular}{|l}
0.309 \\
0.045 \\
-0.004 \\
- \\
\end{tabular} & $\begin{array}{l}0.258 \\
0.208 \\
0.233\end{array}$ & $\begin{array}{l}1.437 \\
0.047 \\
0.000\end{array}$ & $\begin{array}{l}1 \\
1 \\
1\end{array}$ & $\begin{array}{l}1.362 \\
1.046 \\
0.996\end{array}$ & $\begin{array}{l}0.822 \\
0.695 \\
0.631\end{array}$ & $\begin{array}{l}2.256 \\
1.574 \\
1.573\end{array}$ & $\begin{array}{l}0.231 \\
0.829 \\
0.987\end{array}$ & \begin{tabular}{|l}
-0.126 \\
0.411 \\
0.272 \\
-
\end{tabular} & $\begin{array}{l}0.417 \\
0.312 \\
0.347\end{array}$ & $\begin{array}{l}0.092 \\
1.728 \\
0.615\end{array}$ & $\begin{array}{l}1 \\
1 \\
1\end{array}$ & $\begin{array}{l}0.881 \\
1.508 \\
1.313\end{array}$ & $\begin{array}{l}0.389 \\
0.817 \\
0.665\end{array}$ & $\begin{array}{l}1.996 \\
2.782 \\
2.591\end{array}$ & $\begin{array}{l}0.762 \\
0.189 \\
0.433\end{array}$ \\
\hline $\begin{array}{l}\text { Number of trips in the last } 12 \\
\text { month }\end{array}$ & & & & & & & & & & & & & & & & \\
\hline $\begin{array}{l}\text { None } \\
1-3 \text { trips } \\
4-5 \text { trips } \\
6 \text { or more trips (ref) }\end{array}$ & $\begin{array}{l}-0.228 \\
0.181 \\
0.223 \\
- \\
\end{array}$ & $\begin{array}{l}0.391 \\
0.192 \\
0.216\end{array}$ & $\begin{array}{l}0.340 \\
0.894 \\
1.063\end{array}$ & $\begin{array}{l}1 \\
1 \\
1\end{array}$ & $\begin{array}{l}0.796 \\
1.199 \\
1.249\end{array}$ & $\begin{array}{l}0.370 \\
0.823 \\
0.818\end{array}$ & $\begin{array}{l}1.713 \\
1.747 \\
1.907\end{array}$ & $\begin{array}{l}0.560 \\
0.344 \\
0.302\end{array}$ & $\begin{array}{l}0.613 \\
-0.095 \\
-0.328 \\
- \\
\end{array}$ & $\begin{array}{l}0.380 \\
0.266 \\
0.327\end{array}$ & $\begin{array}{l}2.609 \\
0.128 \\
1.008\end{array}$ & $\begin{array}{l}1 \\
1 \\
1\end{array}$ & $\begin{array}{l}1.847 \\
0.909 \\
0.720\end{array}$ & $\begin{array}{l}0.877 \\
0.540 \\
0.380\end{array}$ & $\begin{array}{l}3.888 \\
1.530 \\
1.367\end{array}$ & $\begin{array}{l}0.106 \\
0.720 \\
0.315\end{array}$ \\
\hline $\begin{array}{l}\text { Age } \\
\quad 18-30 \\
31-40 \\
41-50 \\
51-60 \\
61+(\text { ref }) \\
\end{array}$ & $\begin{array}{l}-0.503 \\
0.035 \\
0.172 \\
-0.100 \\
- \\
\end{array}$ & $\begin{array}{l}0.382 \\
0.372 \\
0.368 \\
0.393\end{array}$ & $\begin{array}{l}1.727 \\
0.009 \\
0.218 \\
0.065\end{array}$ & $\begin{array}{l}1 \\
1 \\
1 \\
1\end{array}$ & $\begin{array}{l}0.605 \\
1.036 \\
1.188 \\
0.905\end{array}$ & $\begin{array}{l}0.286 \\
0.500 \\
0.577 \\
0.418\end{array}$ & $\begin{array}{l}1.280 \\
2.146 \\
2.444 \\
1.957\end{array}$ & $\begin{array}{l}0.189 \\
0.925 \\
0.640 \\
0.799\end{array}$ & $\begin{array}{l}-0.078 \\
-0.316 \\
-0.639 \\
-0.337 \\
- \\
\end{array}$ & $\begin{array}{l}0.498 \\
0.508 \\
0.522 \\
0.536\end{array}$ & $\begin{array}{l}0.024 \\
0.387 \\
1.501 \\
0.394\end{array}$ & $\begin{array}{l}1 \\
1 \\
1 \\
1\end{array}$ & $\begin{array}{l}0.925 \\
0.729 \\
0.528 \\
0.714\end{array}$ & $\begin{array}{l}0.348 \\
0.270 \\
0.190 \\
0.250\end{array}$ & $\begin{array}{l}2.457 \\
1.972 \\
1.467 \\
2.043\end{array}$ & $\begin{array}{l}0.876 \\
0.534 \\
0.221 \\
0.530\end{array}$ \\
\hline $\begin{array}{l}\text { Gender } \\
\quad \text { Female } \\
\text { Male (ref) }\end{array}$ & $\begin{array}{l}0.388 \\
-\end{array}$ & 0.213 & 3.325 & 1 & 1.474 & 0.971 & 2.236 & 0.068 & $\begin{array}{l}0.167 \\
-\end{array}$ & 0.277 & 0.364 & 1 & 1.182 & 0.686 & 2.036 & 0.547 \\
\hline
\end{tabular}

Model Fitting Information: AIC=587.982, BIC=705.136, -2 Log Likelihood=539.982, $\chi 2=38.802(\mathrm{df}=22, \mathrm{p}=0.015)$. Nagelkerke Pseudo R-Square $=0.048$ 
Table 4. Motives, preferred transport and accompanying person according to income and travel experience




Table 5. Motives, preferred transport and accompanying person, according to age and gender of respondents

\begin{tabular}{|c|c|c|c|c|c|c|c|c|}
\hline & \multirow{2}{*}{\multicolumn{5}{|c|}{ Age (years old) }} & & & \\
\hline & & & & & & \multicolumn{2}{|l|}{ Gender } & \multirow[t]{2}{*}{ Total } \\
\hline & $\begin{array}{l}18- \\
30\end{array}$ & $1-40$ & $41-50$ & $51-60$ & $61+$ & Female & Male & \\
\hline \multicolumn{9}{|c|}{ Motivation } \\
\hline Relaxation & 99 & 141 & 136 & 55 & 18 & 369 & 80 & 449 \\
\hline Sightseeing and Culture & 62 & 49 & 66 & 51 & 24 & 205 & 47 & 252 \\
\hline Business & 15 & 17 & 22 & 14 & 0 & 38 & 30 & 68 \\
\hline Education & 6 & 2 & 2 & 0 & 0 & 8 & 2 & 10 \\
\hline Meeting friends and relatives & 49 & 42 & 35 & 22 & 5 & 132 & 21 & 153 \\
\hline Other & 19 & 6 & 13 & 3 & 1 & 28 & 14 & 42 \\
\hline & \multicolumn{5}{|c|}{$\chi^{2}=59.239(\mathrm{df}=20, \mathrm{p}=0.000)$} & \multicolumn{2}{|c|}{$\begin{array}{c}\chi^{2}=34.879 \\
(\mathrm{df}=5, \mathrm{p}=0.000)\end{array}$} & \\
\hline \multicolumn{9}{|c|}{ Preferred transport } \\
\hline Own car & 146 & 149 & 171 & 61 & 14 & 448 & 93 & 541 \\
\hline Air transport & 73 & 77 & 67 & 45 & 21 & 222 & 61 & 283 \\
\hline Train & 13 & 2 & 8 & 2 & 1 & 16 & 10 & 26 \\
\hline Tour bus & 9 & 23 & 22 & 33 & 10 & 77 & 20 & 97 \\
\hline Other & 9 & 6 & 6 & 4 & 2 & 17 & 10 & 27 \\
\hline & \multicolumn{5}{|c|}{$\chi 2=72.483(\mathrm{df}=16, \mathrm{p}=0.000)$} & \multicolumn{2}{|c|}{$\begin{array}{c}\chi^{2}=13.594 \\
(\mathrm{df}=4, \mathrm{p}=0.000)\end{array}$} & \\
\hline \multicolumn{9}{|c|}{ Accompanying person } \\
\hline Family & 91 & 161 & 177 & 59 & 10 & 425 & 73 & 498 \\
\hline Friends & 86 & 41 & 42 & 38 & 19 & 166 & 60 & 226 \\
\hline Spouse & 44 & 33 & 28 & 29 & 12 & 125 & 21 & 146 \\
\hline Business colleagues & 9 & 7 & 13 & 9 & 1 & 24 & 15 & 39 \\
\hline Alone & 20 & 15 & 14 & 10 & 6 & 40 & 25 & 65 \\
\hline & \multicolumn{5}{|c|}{$\chi^{2}=91.311(\mathrm{df}=16, \mathrm{p}=0.000)$} & \multicolumn{2}{|c|}{$\begin{array}{c}\chi^{2}=40.089 \\
(\mathrm{df}=4, \mathrm{p}=0.000)\end{array}$} & \\
\hline Total & 250 & 257 & 274 & 145 & 48 & 780 & 194 & 974 \\
\hline
\end{tabular}




\begin{tabular}{|c|c|c|c|c|c|c|}
\hline & \multirow[t]{2}{*}{ Mean } & \multirow{2}{*}{$\begin{array}{l}\text { Standard } \\
\text { deviation }\end{array}$} & \multirow{2}{*}{$\begin{array}{l}\text { t-test } \\
\text { Gender }\end{array}$} & \multicolumn{3}{|l|}{ F-test } \\
\hline & & & & Age & Income & $\begin{array}{l}\text { Travel } \\
\text { experience }\end{array}$ \\
\hline $\begin{array}{l}\text { I will chose my trips depending on the } \\
\text { health safety of the destination }\end{array}$ & 3.89 & 1.078 & $-5.647 * * *$ & $4.095 * *$ & 2.013 & 1.171 \\
\hline $\begin{array}{l}\text { I will take extra hygiene precautions in } \\
\text { my future trips }\end{array}$ & 4.07 & 0.964 & $-4.698 * * *$ & $3.005^{*}$ & 0.579 & 1.014 \\
\hline $\begin{array}{l}\text { I will avoid crowds whenever it is } \\
\text { possible }\end{array}$ & 3.92 & 1.016 & $-5.079 * * *$ & $10.558 * * *$ & 0.258 & 1.082 \\
\hline
\end{tabular}

possible

Notes: 1. Coding: 1-Strongly disagree, 5-Strongly agree;

2. Levels of significance: $* * * \mathrm{p}<0.001, * * \mathrm{p}<0.01, * \mathrm{p}<0.05$

Table 7. Level of importance of travel decision factors after the pandemic

\begin{tabular}{|c|c|c|c|c|c|c|}
\hline & \multirow[t]{2}{*}{ Mean } & \multirow{2}{*}{$\begin{array}{l}\text { Standard } \\
\text { deviation }\end{array}$} & \multirow{2}{*}{$\begin{array}{l}\text { t-test } \\
\text { Gender }\end{array}$} & \multicolumn{3}{|l|}{ F-test } \\
\hline & & & & Age & Income & $\begin{array}{l}\text { Travel } \\
\text { experience }\end{array}$ \\
\hline $\begin{array}{l}\text { Travel to a remote/isolated } \\
\text { destination }\end{array}$ & 2.67 & 1.060 & $-2.021 *$ & 1.721 & 0.269 & 0.608 \\
\hline Staying at a remote/isolated hotel & 2.60 & 1.057 & $-2.460 *$ & $3.961 * *$ & 0.468 & 2.545 \\
\hline $\begin{array}{l}\text { Staying at a small hotel rather } \\
\text { than big one }\end{array}$ & 3.02 & 1.116 & $-4.206^{* * *}$ & $5.439 * * *$ & 1.719 & 0.707 \\
\hline $\begin{array}{l}\text { In the destination there is a } \\
\text { reliable health system that I can } \\
\text { access }\end{array}$ & 3.56 & 1.025 & $-6.551 * * *$ & $2.609 *$ & 1.631 & 1.892 \\
\hline $\begin{array}{l}\text { At the accommodation there is } \\
\text { good disinfection control of } \\
\text { rooms and facilities }\end{array}$ & 3.87 & 0.984 & $-5.743 * * *$ & $2.861 *$ & 0.664 & $2.690 *$ \\
\hline $\begin{array}{l}\text { There are masks and hand } \\
\text { sanitizers provided for the } \\
\text { passengers }\end{array}$ & 3.32 & 1.148 & $-5.107 * * *$ & $5.686 * * *$ & 2.161 & 1.715 \\
\hline $\begin{array}{l}\text { The destination attracts many } \\
\text { tourists }\end{array}$ & 2.71 & 1.049 & 0.288 & 0.170 & $4.782 * *$ & 0.755 \\
\hline $\begin{array}{l}\text { The hotel provides enough } \\
\text { common space for physical } \\
\text { distancing }\end{array}$ & 3.47 & 1.066 & $-5.045^{* * *}$ & $6.780 * * *$ & 0.881 & $2.944^{*}$ \\
\hline
\end{tabular}

Notes: 1. Coding: 1-Not important at all, 5-Expremely important; 2. Levels of significance: $* * * p<0.001, * * p<0.01, * p<0.05$ 